\title{
Does Cry1Ac Bt-toxin impair development of worker larvae of Africanized honey bee?
}

\author{
M. A. P. Lima1 ${ }^{1}$, C. S. S. Pires ${ }^{2}$, R. N. C. Guedes ${ }^{1}$, E. Y. T. Nakasu², M. S. Lara ${ }^{3}$, E. M. G. Fontes², E. R. Sujii ${ }^{2}$, \\ S. C. Dias ${ }^{4}$ \& L. A. O. Campos ${ }^{3}$ \\ 1 Departamento de Biologia Animal, Universidade Federal de Viçosa, Viçosa, Brazil \\ 2 Embrapa, Cenargen, Brasília, Brazil \\ 3 Departamento de Biologia Geral, Universidade Federal de Viçosa, Viçosa, Brazil \\ 4 Centro de Análises Proteômicas e Bioquímicas, Universidade Católica de Brasília, Brasília, Brazil
}

\section{Keywords}

Bt cotton, GMO, pollinator larvae, risk

assessment, transgenic plants

\section{Correspondence}

Maria Augusta Pereira Lima, Departamento de Biologia Animal, Universidade Federal de Viçosa, Viçosa, MG 36570-000, Brazil.

E-mail:maugusta@ufv.br

Received: March 18, 2010; accepted: July 4, 2010

doi: 10.1111/j.1439-0418.2010.01573.x

\begin{abstract}
The western honey bee (Apis mellifera L.) is a widespread pollinator species. The present study aimed to test if Africanized honey bee larvae are negatively affected by the ingestion of diet contaminated with the Bacillus thunringiensis toxin Cryl Ac, which is expressed in GM cotton plants. The toxin activity was confirmed in bioassays with the velvetbean caterpillar (Anticarsia gemmatalis), a soybean pest species susceptible to Cryl Ac. The honey bee larvae were subjected to ingestion of either pure larval diet (control), diluted larval diet (diluted control) or larval diet diluted in a CrylAc solution at a concentration compatible with the maximum possible field exposure. Although diluted diet slightly increased larval mortality, CrylAc ingestion did not affect survival, developmental time, and neither adult body mass nor size, indicating that GM plants are unlikely to significantly impair the development of honey bee larvae. The larval-rearing system reported here was suitable to assess the lethal and sub-lethal effects of GM expressed toxins against honey bee larvae.
\end{abstract}

\section{Introduction}

Pollinators in general, and honey bees in particular, encompass a group of beneficial insects that can be potentially affected by pollen and nectar ingestion from genetically modified (GM) plants expressing toxic proteins in such resources (Malone and PhamDelègue 2001; O'Callaghan et al. 2005). Therefore, environmental risk assessment of GM plants should contemplate their potentially negative effect on this group of non-target species (Arpaia et al. 2006; Craig et al. 2008).

The area cultivated with GM crops expressing Bacillus thuringiensis-derived protein toxins (Bt-toxins) is quickly expanding in several countries. The current commercial Bt plant varieties express the toxin in several tissues, including pollen, the main energy source for bees (Crailshein 1990; Greenplate 1997, 1999). Thus, the harvest of floral resources can expose foraging bees to contact with pollen expressing Bt toxins, which are later provided to the developing larvae within the hive. Therefore, specific methods are required to assess the potential effects of such toxins on honey bee adults, as well as larvae.

The commercial cultivation of Bt cotton expressing the CrylAc toxin in Brazil was approved in 2005. Bees are the main floral visitors in cotton plants and the africanized honey bee Apis mellifera L. is the most abundant in Brazil (Arpaia et al. 2006). This species is also considered the main cotton pollinator in several parts of the world (Free 1993). It is not surprising, therefore, that several risk analysis of Bt plants (including cotton) have used the honey bee as 
model species because of its importance as pollinator and honey producer (Allen-Wardell et al. 1998).

The majority of the risk assessment studies with $\mathrm{Bt}$ plants on pollinators studied only honey bee adult foragers ( $\mathrm{O}^{\prime}$ Callaghan et al. 2005; Babendreier et al. 2007; Rose et al. 2007; Liu et al. 2009). However, an increase in larval mortality caused by Bt toxin exposure to honey bee larvae may lead to a decrease on the hive population with reduction in the pollination service (van der Steen 2001). The larval food of honey bee constitutes of pollen among other items and, as the larvae are unable to select their own food to which they are continuously exposed, they are probably more exposed to the Bt toxins than the adults and in a more critical developmental stage (Brødsgaard et al. 2003; Babendreier et al. 2004).

Studies of the effect of larval food on the honey bee development cannot be carried out in the hive because of the continuous detection and removal of sick larvae from the hive by the nurse bees (Brødsgaard et al. 2000). Additionally, in vitro rearing techniques have been developed for honey bee larvae by several authors (Brødsgaard et al. 1998; McKee et al. 2004; Aase et al. 2005; Aupinel et al. 2005; Silva et al. 2009).

Some studies have been carried out assessing honey bee larval mortality and sub-lethal effects under feeding exposure to different proteins synthesized by insect-resistant GM plants under controlled conditions (Malone et al. 2002; Brødsgaard et al. 2003; Lehrman 2007) or within the hive itself (Arpaia 1996; Hanley et al. 2003). However, the mortality and developmental effects of the CrylAc provided in the larval diet has yet to be investigated in the honey bee, which was our objective.

The risk analysis of GM plants to bees, as proposed for other non-target organisms, should encompass tests carried out in laboratory, confinement conditions and in the field (Dechaume-Moncharmont et al. 2005; Arpaia et al. 2006; Andow et al. 2008). In laboratory, the bees should be subjected to high concentrations of the purified protein (Malone et al. 2004; Dechaume-Moncharmont et al. 2005), following the premise of the 'worst possible scenario' (Wilkinson et al. 2003; Wilkinson 2004).

Besides mortality, a judicious analysis should involve potential sub-lethal effects of toxins on nontarget insects (Desneux et al. 2007). Among these effects, bee development and size are traits to be considered because $\mathrm{Bt}$ toxins act in the insect midgut potentially reducing or interrupting feeding, consequently leading to the formation of smaller adults (Gill et al. 1992). As larger bees are more efficient pollinators and transport heavier pollen and nectar loads (Klostermeyer et al. 1973; Pyke 1978), a reduction in the forager size may have negative effect in the hive and in the pollination service.

If honey bee foragers collect pollen in Bt plants, this food will be provided to the larvae. In this case, the larvae may suffer lethal and sub-lethal effects of such exposure depending on amount of the ingested toxin. To test the hypotheses that the ingestion of CrylAc toxin expressed in pollen from GM cotton plants negatively affects worker bee larvae of A. mellifera, the present study was carried out to verify if the ingestion of the CrylAc toxin by the larvae (i) increases mortality or impairs development and (ii) smaller workers are produced as a result of such exposure, potentially compromising the foraging capacity of the hive.

\section{Material and Methods}

\section{Insects and CrylAc protein}

Five colonies of the africanized honey bee A. mellifera were field-collected at Viçosa municipality, Minas Gerais State, Brazil $\left(20^{\circ} 45^{\prime} \mathrm{S} 42^{\circ} 52^{\prime} \mathrm{W}\right)$ from February to December 2005. The colonies were kept in Langstroth box hives to obtain the larvae. The queens remained confined in pre-established place within each brood chamber for $6-8 \mathrm{~h}$ to control brood age. All of the material used for the experimental set up, larvae removal, diet preparation and placement were autoclaved or sterilized in germicide UV light in a biosafety chamber.

The CrylAc protein used in the experiments was provided by the Biochemistry Department of the Case Western Reserve University (Cleveland, $\mathrm{OH}$ ) in the purified active form (lyophilized). The toxin was stored at $-15^{\circ} \mathrm{C}$ and dissolved in distilled and autoclaved water immediately before use in the experiments.

\section{Toxin bioactivity}

The insecticidal activity of the Cryl Ac toxin was verified in bioassays with velvetbean caterpillar (Anticarsia gemmatalis) (Lepidoptera: Noctuidae), which is susceptible to this toxin. The protein was diluted in water and sprayed on the caterpillar diet and provided to second instar larvae. The treatments used were: (i) artificial diet sprayed with pure water and (ii) artificial diet sprayed with $50 \mu \mathrm{g}$ CrylAc diluted in water. The same water volume was used in both treatments and the amount of CrylAc used 
corresponded to the toxic concentrations for the caterpillars reported by Wright et al. (1997) and Cerda et al. (2003). Each bioassay was replicated eight times using 30 caterpillars for each treatment in each replicate. The caterpillars were observed for 7 days and their mortality was used as an indication of the insecticidal activity of the CrylAc toxin available for the honey bee study.

\section{Rearing honey bee larvae}

Honey bee larvae were reared using artificial diet based on royal jelly and methods by Silva et al. (2009). This diet was offered to the larvae individually maintained in polyethylene artificial blood cells (9.8 $\mathrm{mm}$ high, $5.6 \mathrm{~mm}$ wide at the base and $8.8 \mathrm{~mm}$ wide at the top), previously mounted in Petri dishes, using a perforated polystyrene disk as base. Forty indentified cells were placed in each Petri dish. These cells were filled with diet $(4 \mu \mathrm{l})$ right before transferring the larvae.

The artificial diet contained $49.5 \%$ royal jelly, $36.3 \%$ water, $6.8 \% \mathrm{D}$-fructose, $6.8 \% \mathrm{D}$-glucose and $1.1 \%$ yeast extract (Silva et al. 2009). The sugars and yeast extract were dissolved in water, and filtered through a Millipore membrane $(0.22 \mu \mathrm{m})$. This solution was subsequently mixed with the royal jelly. The diet was homogenized and stored at $5^{\circ} \mathrm{C}$ for no longer than 6 days in sterile glass flasks covered in aluminium foil. The diet was always heated in water bath at $34^{\circ} \mathrm{C}$ for 5 min before use.

The brood chambers containing worker larvae were obtained from hives and transferred to the laboratory. First instar larvae (up to 24-h-old) were collected from chambers using a metal scalpel with a $90^{\circ}$ bend tip and placed over the diet contained within the artificial cells. The larvae were observed under stereomicroscope after the transfer to verify if all individuals used in the bioassay were alive. The larvae that did not exhibit spiracle movement were considered dead, and therefore they were discharged and replaced by live individuals.

\section{Cryl Ac bioassay with honey bee worker larvae}

Each bioassay was replicated five times using 40 larvae collected at the five available colonies, totalizing 200 individuals studied per each treatment (5 replicates $\times 40$ larvae). The larvae were subjected to one of following treatments - (i) pure larval diet (164 $\mu \mathrm{l}$ diet consecutively provided; control), (ii) diluted larval diet (164 $\mu$ l diet consecutively provided $+4.2 \mu \mathrm{l}$ sterile water; diluted control), (iii) larval diet diluted in a CrylAc solution at a concentration compatible with the maximum possible field exposure (164 $\mu \mathrm{l}$ diet consecutively provided $+4.2 \mu \mathrm{l}$ sterile water containing $50 \mu \mathrm{g}$ CrylAc).

The dose of $50 \mu \mathrm{g}$ CrylAc per larva was used because it is the toxic dose (and thus lethal) to the target species (Wright et al. 1997; Cerda et al. 2003). The transgenic cotton Bollgard $\AA$ expresses the CrylAc toxin in its pollen at the concentration of $0.6 \mu \mathrm{g} / \mathrm{g}$ (Greenplate 1997). Honey bee larvae consume a maximum of $2 \mathrm{mg}$ of pollen during development (Babendreirer et al. 2004). Assuming that under field conditions each honey bee larva feeds only on pollen from Bt cotton, each larva will ingest $1.2 \mathrm{ng}$ of CrylAc, amount far lower than what was provided to the larvae in the present study. Therefore, the high dose of CrylAc provided to the honey bee larvae is in accordance with the worst case scenario, justifying its use in the present study.

The larvae were fed for five consecutive days, counted from the transferring day, with the provision of $4,15,25,50$ and $70 \mu \mathrm{l}$ of diet, respectively every day in all treatments. The amount of daily diet provided was determined based on the best amount of diet provided to larvae of first, second, third, fourth and fifth days (Silva et al. 2009). The larvae were fed with the exact amount of diet necessary to nourish them before the new provisioning. Therefore, along the days, there was not residual diet inside the rearing cells. The larvae were kept in the same rearing cells until adult emergence, to avoid larval injures caused by manipulation.

The Petri dishes (containing the 40 larvae of each replicate) were placed in desiccators to better control humidity and prevent microorganism contamination. The desiccators were maintained in a B.O.D. incubator at $34^{\circ} \mathrm{C}, 99 \%$ relative humidity and $24 \mathrm{~h}$ dark until adult emergence. The position of the desiccators within the B.O.D. incubator was randomly established to avoid any bias because of gradients within the incubator.

Daily mortality and developmental time of larvae and pupae were recorded. Dead individuals were discharged and the bees that completed development were collected within $24 \mathrm{~h}$ of emergence and subsequently chilled. The body mass of each individual was recorded in an analytical balance. The newly emerged bees were fixed in a methanol:acetic acid solution (3:1) for $24 \mathrm{~h}$ and maintained in $70 \%$ ethanol. Morphometric determinations were subsequently carried out in each individual using micrometric ocular coupled to stereomicroscope. The 
morphological traits measured were: head width (maximum distance between the outer edges of the compound eyes), and intertegular distance (minimum distance between the tegulae edges) (Bosch and Vicens 2002). The measurements were converted to $\mathrm{mm}$.

\section{Statistical analyses}

Mortality of velvetbean caterpillar among treatments was compared by Student's $t$ test $(\mathrm{P}<0.05)$ after verifying normality and homoscedasticity. Survival analysis was carried out to recognize potential differences in bee mortality during development under the different treatments. The survival curves were obtained through Kaplan-Meier estimators generated from the proportion of honey bee larvae surviving each day from the beginning to the end of the experiment using the procedure LIFETEST from SAS (SAS Institute 2001). The bees that survived until emergence (18th day) were treated as censored data (Allison 1998). The survival curves of each treatment were compared using the Cox's regression method (PHREG procedure from SAS; SAS Institute 2001). The developmental time, body mass and morphometric determinations (head width and intertegular distance) of adult bees were subjected to analyses of variance (ANOVA), again after verifying normality and homoscedasticity; data transformation was not necessary. Bee mortality was subsequently correlated to body mass and morphometric measurements using the procedure CORR from SAS (SAS Institute 2001).

\section{Results}

\section{CrylAc bioactivity towards target caterpillar}

The insecticidal activity of CrylAc toxin available for the honey bee experiments was confirmed against the velvetbean caterpillar. Compared with the control, larval mortality was significantly higher when provided with CrylAc-contaminated diet $\left(t_{14,8}=27.72\right.$; $\mathrm{P}<0.0001)$.

\section{Rearing honey bee larvae}

The method used for rearing honey bee larvae was suitable for the high-dose exposure test of Cry toxic effect on honey bee larvae, as $81.0 \pm 3.7 \%$ of the larvae survived in the control treatment (in about 9 days; fig. 1). The survival reduced to around 65\% considering the overall life cycle (larval and pupal

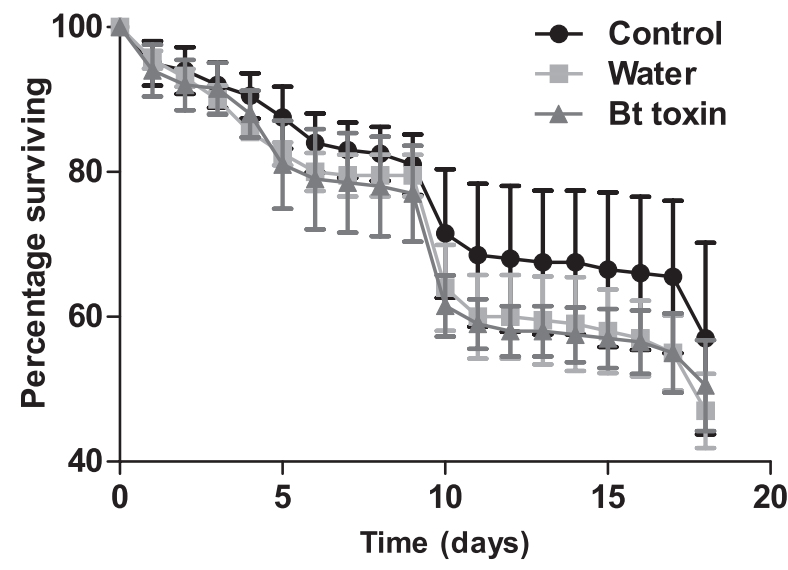

Fig. 1 Survival curves of workers of africanized honey bee (mean SE) fed with larval diet (control), diluted larval diet and larval diet mixed with a solution of Bt toxin and water. Each larva received $50 \mu \mathrm{g}$ of Cry1Ac. Kaplan-Meier estimates of the life-time distributions were obtained by pooling all the bioassays ( 40 bees per bioassay) for each treatment.

stages) with some badly formed pupae failing to emerge regardless of the treatment (fig. 1).

\section{Effect of CrylAc in honey bee worker larvae}

The survival curves obtained using Kaplan-Meier estimators indicate low although significant larval mortality with development $\left(\chi^{2}=159.82 ; \mathrm{P}<0.001\right.$; fig. 1), as expected. The survival curves were significantly affected by the addition of water to the diet $\left(\chi^{2}=26.55 ; \mathrm{P}<0.001\right)$, as shown by the comparison with the control treatment containing pure larval diet, which exhibited higher larval survival (fig. 1). Therefore, the addition of water to the diet to convey the CrylAc toxin led to a small, but significant increase in larval mortality. The toxin itself did not significantly interfere with the survival of worker honey bee larvae and pupae throughout their development, because survival under the diluted diet with and without CrylAc was similar (fig. 1). Larval survival under diluted diet with and without CrylAc was $79.5 \pm 5.9 \%$ and $77.0 \pm 5.9 \%$ respectively.

Insects fed with the three different diets (pure, water diluted and water diluted containing Cryl Ac) did not exhibit significant differences in development. The CrylAc toxin did not affect larval and pupal developmental time $\left(\mathrm{F}_{2,12}=1.0, \mathrm{P}=0.38\right.$; and $\mathrm{F}_{2,12}=0.1, \mathrm{P}=0.92$, respectively) (fig. 2 ). The body mass of newly emerged worker bees was not affected by CrylAc either $\left(\mathrm{F}_{2,12}=0.67, \mathrm{P}=0.53\right.$; fig. 3$)$, nor were the morphometric measures head capsule 


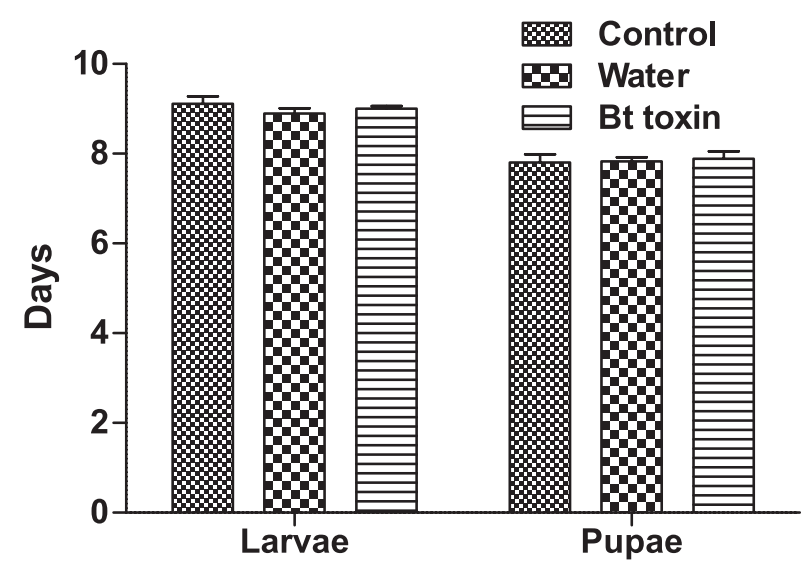

Fig. 2 Mean developmental time ( \pm SE) from larval and pupal stages of workers of Africanized honey bee when feeding on different larval diets.

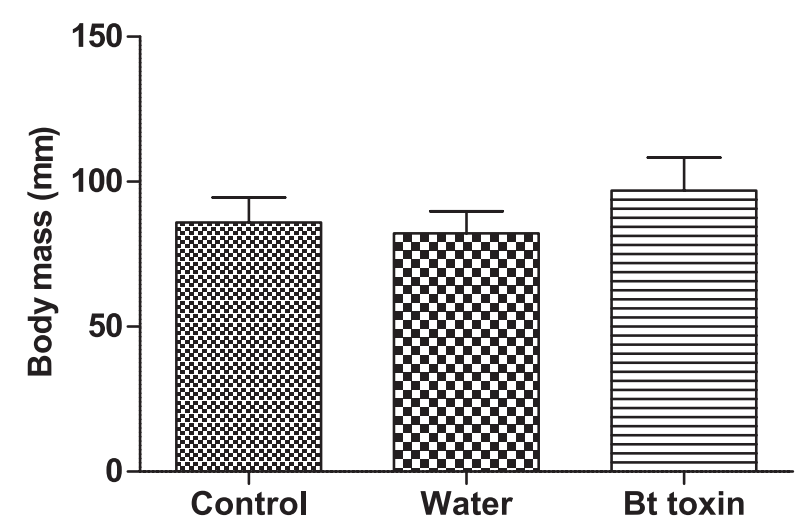

Fig. 3 Mean body mass ( \pm SE) from newly emerged workers of africanized honey bee fed on different larval diets.

width $\left(\mathrm{F}_{2,12}=0.14, \mathrm{P}=0.87\right)$ and intertegular distance $\left(\mathrm{F}_{2,12}=0.01, \mathrm{P}=0.99\right)$ (fig. 4$)$, which are indicators of adult size at emergence.

Body mass, head capsule width and intertegular distance were all significantly and negatively correlated with insect mortality (table 1). The morphometric measures were significantly correlated with each other $(\mathrm{r}=0.61, \mathrm{P}=0.001)$.

\section{Discussion}

The methods used to rear worker larvae of honey bees under controlled laboratory conditions (Silva et al. 2009) were suitable for toxicity assessment of CrylAc toxins and can be also adapted to test other toxins produced by transgenic crops. The final mortality observed in the control (pure larval diet) was below $50 \%$ and was lower than the mortality usu-

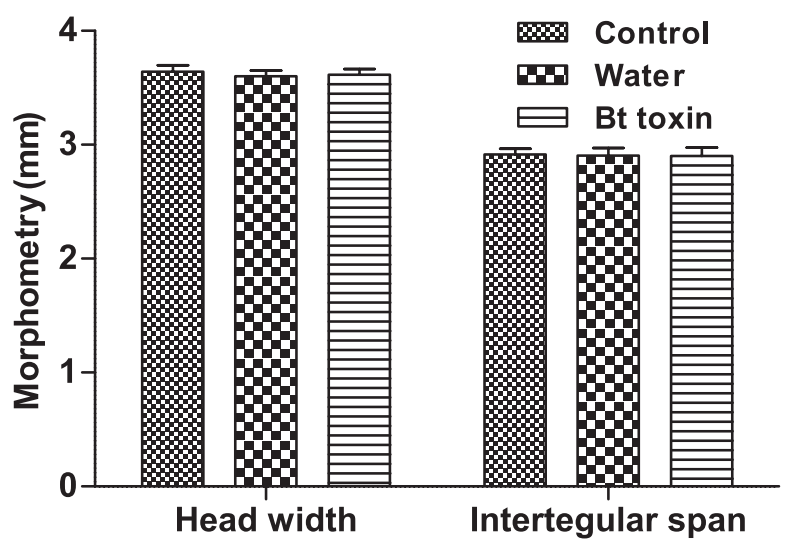

Fig. 4 Mean morphometric measurements ( \pm SE) from newly emerged workers of Africanized honey bee fed on different larval diets.

Table 1 Correlations between adult body mass and morphometrical traits with mortality of africanized honey bee workers (Apis mellifera) with and without exposure to Cry1Ac-contaminated diet

\begin{tabular}{lll}
\hline Variable & $r$ & $P$ \\
\hline Body mass (mg) & -0.69 & $0.004^{\star}$ \\
Intertegular distance (mm) & -0.68 & $0.005^{\star}$ \\
Head width (mm) & -0.81 & $0.0003^{*}$ \\
\hline
\end{tabular}

*Significant correlation at $P<0.05(n=15)$.

ally verified under in vitro rearing of honey bee larvae, even without providing additives (Vandenber and Shimanuki 1987; Malone et al. 2002), which can be caused by mechanical injuries (McKee et al. 2004). The larvae rearing in wax brood chambers may be an alternative to further increase bee survival in future studies, because the wax provides better thermal isolation (Vandenberg and Shimanuki 1987). In addition, the toxins should preferably be directly diluted in the water already used in the diet preparation, because the addition of only $2.5 \%$ in the water content of the diet significantly increased larval mortality. According to Vandenberg and Shimanuki (1987), the diet used for rearing honey bee larvae should have $30 \%$ of total solids and this proportion was modified when we diluted the diet. As we treated the larvae with an artificial diet, probably even few modifications on their composition could cause physiological alterations that could lead to a higher mortality rate in immature bees.

The results of our experiments refute the hypothesis that the ingestion of high doses of CrylAc by honey bee larvae increases mortality, developmental 
time and size of adult worker bees. After ingestion of CrylAc, worker larvae turned into pupae and adults under normal developmental time and survival rate, exhibiting body mass and morphometric traits similar to those of bees reared on diet without the toxin. Only the provision of diluted diet led to a significant, although small, increase in larval mortality. Therefore, our results demonstrate that CrylAc toxin expressed in transgenic cotton plants does not exhibit detrimental lethal and developmental effects on honey bee larvae.

As the honey bee larvae were exposed to the activated form of the CrylAc toxin, it seems that these insects do not possess the specific gut receptors necessary for the toxin binding. In susceptible insects, the toxicity of the CrylAc toxin takes place with the binding of the $\mathrm{Bt}$ protein monomers to receptors of the midgut membrane (Gill et al. 1992). These monomers subsequently aggregate leading to formation of pores in the midgut epithelium. An ionic and $\mathrm{pH}$ unbalance consequently takes place in the haemolymph and midgut lumen causing the individual death caused by feeding inhibition or to septicaemia (Höfte and Whiteley 1989; Gill et al. 1992; Bravo et al. 2005).

Despite of the high doses of CrylAc toxin used in our experiments, far higher than the concentrations expressed in the cotton pollen, the lack of toxic effect in laboratory does not eliminate the possibility of occurrence of climate-dependent effects in fieldcultivated cotton plants. Hive-stored Bt toxins probably do not affect survival, development and size of worker bees ingesting them. However, indirect effects, like phenotypic plant alterations, not considered in our experiments, may increase repellence of foraging bee workers (Malone and Pham-Delègue 2001; Babendreier et al. 2008). Recently, RamirezRomero et al. (2008) showed that the ingestion of high doses of Cryl Ab protein negatively affected the feeding behaviour of honey bee workers. In addition, learning capacity of treated bees, associated with foraging behaviour, was modified when compared with untreated workers. Therefore, sub-lethal effects of Bt toxins, including ethological evaluations, should be also studied for a complete risk assessment.

The negative correlations between mortality and body mass and size indicate that the surviving worker bees emerging from higher mortality treatments exhibit higher body mass and size. As the variables body mass and size (morphometric traits) were highly and positively correlated, the use of only one of them is sufficient to consider in future studies.
Previous studies with honey bees concluded that different Bt toxins did not affect adult (imago) workers (O'Callaghan et al. 2004; Duan et al. 2008) and larvae (Arpaia et al. 1996; Hanley et al. 2003). However, the CrylAc toxin had only been tested on adult honey bee workers (Liu et al. 2005, 2009), and on larvae and adults of Bombus accidentalis and B. impatiens (Morandin and Winston 2003). These studies also did not show evidence of any deleterious effects of CrylAc on honey bees and bumble bees, in accordance with this study.

The methods employed in our experiments with worker honey bee larvae were suitable for the toxicological assessment of the CrylAc toxin and could be used for other toxins. However, suitable methods for testing honey bee larvae originating queens and drones have yet to be developed. The great majority of the risk analysis studies of GM plants on bees focused only in adult workers. Only few investigations considered worker larvae such as in our present study, and queens and drones have been neglected so far. Furthermore, the lack of evidence of direct effects of toxins from GM plants in bees does not necessarily imply lack of significant indirect effect on their colonies. This requires complementary experiments of field-exposure for a complete risk assessment of Cry protein exposure by bees.

\section{Acknowledgements}

The financial support provided by the National Council of Scientific and Technological Development (CNPq), Minas Gerais State Foundation for Research Aid (FAPEMIG) were greatly appreciated and acknowledged here.

\section{References}

Aase ALTO, Amdam GV, Hagen A, Omholt ST, 2005. A new method for rearing genetically manipulated honey bees workers. Apidologie 36, 293-299.

Allen-Wardell G, Bernhardt P, Bitner R, Burquez A, Buchmmann S, Cane J, Cox Pa, Dalton V, Feinsinger $\mathrm{P}$, Ingram M, Inouye D, Jones CE, Kennedy K, Kevan P, Koopowitz H, Medellin R, Medellin-Morales S, Nabhna GP, Pavlik B, Tepedino V, Torchio P, Walker S, 1998. The potential consequences of pollinator declines on the conservation of biodiversity and stability of food crop yields. Conserv. Biol. 12, 8-17. Allison PD, 1998. Survival analysis using the SAS system. A pratical guide. SAS Institute Inc., Cary, NC.

Arpaia S, 1996. Ecological impact of Bt-transgenic plants: 1. assessing possible effects of CryIIIB toxin on honey 
bee (Apis mellifera L.) colonies. J. Genet. Breed. 50, 315-319.

Arpaia S, Imperatriz-Fonseca VL, Pires CSS, Silveira FS, 2006. Non-target and biodiversity impacts on pollinators and flower visiting insects. In: Environmental risk assessment of genetically modified organisms: methodologies for assessing Bt cotton in Brazil. Ed. by Hilbeck A, Andow D, Fontes E, CABI Publishing, Cambridge, 155-174.

Aupinel P, Fortini D, Dufour H, Tasei JN, Michaud B, Odoux JF, Pham-Delègue $\mathrm{M}-\mathrm{H}, 2$ 2005. Improvement of artificial feeding in a standard in vitro method for rearing Apis mellifera larvae. Bull. Insectol. 58, 107-111.

Babendreier D, Kalberer N, Romeis J, Fluri P, Bigler F, 2004. Pollen consumption in honey bee larvae: a step forward in the risk assessment of transgenic plants. Apidologie 35, 293-300.

Babendreier D, Joller D, Romeis J, Bigler F, Widmer F, 2007. Bacterial community structures in honeybee intestines and their response to two insecticidal proteins. Microbiol. Ecol. 59, 610.

Babendreier D, Reichhart B, Romeis J, Bigler F, 2008. Impact of transgene products on the behaviour and performance of bumble bee micro colonies. Entomol. Exp. Appl. 126, 148-157.

Bosch J, Vicens N, 2002. Body size as an estimator of production costs in a solitary bee. Ecol. Entomol. 27, 129-137.

Brødsgaard CJ, Ritter W, Hansen H, 1998. Response of in vitro reared honey bee larvae to various doses of Paenibacillus larvae larvae spores. Apidologie 29, 569-578.

Brødsgaard CJ, Ritter W, Hansen H, 2000. Progress of Paenibacillus larvae larvae infection in individually inoculated honey bee larvae reared singly in vitro, in micro colonies, or in full-size colonies. J. Apicult. Res. 39, 19-27.

Brødsgaard HF, Brødsgaard CJ, Hansen H, Lövei GL, 2003. Environmental risk assessment of transgene products using honey bee (Apis mellifera) larvae. Apidologie 34, 139-145.

Cerda H, Sayyed AH, Wright DH, 2003. Laboratory culture conditions affect stability of resistance to Bacillus thuringiensis Cryl Ac in Plutella xylostella (Lep. Plutellidae). J. Appl. Entomol. 127, 142-145.

Craig W, Tepfer M, Degrassi G, Ripandelli D, 2008. An overview of general features of risk assesmentes of genetically modified crops. Euphytica 164, 853-880.

Crailshein K, 1990. The protein balance of the honey bee worker. Apidologie 21, 417-429.

Dechaume-Moncharmont FX, Azzouz H, Pons O, PhamDelègue MH, 2005. Soybean proteinase inhibitor and the foraging strategy of free flying honeybees. Apidologie $36,421-430$.
Desneux ND, Decourtye A, Deupuech JM, 2007. The sublethal effects on beneficial arthropods. Annu. Rev. Entomol. 52, 81-106.

Duan JJ, Marvier M, Huesing J, Dively G, Huang ZY, 2008. A meta-analysis of effects of Bt crops on honey bees (Hymenoptera: Apidae). PLoS ONE; 3, e1415. doi: 10.1371/journal.pone.0001415.

Free JB, 1993. Insect pollination of crops. Academic Press, Londres, 684.

Gill SS, Cowles EA, Pietrantonio PV, 1992. The mode of action of Bacillus thuringiensis endotoxins. Annu. Rev. Entomol. 37, 615-634.

Greenplate JT, 1997. Response to reports of early damage in 1996 commercial Bt-transgenic cotton (Bollgard ${ }^{\circledR}$ ) plantings. Soc. Invertebr. Pathol. Newsl. 29, 15-18.

Greenplate JT, 1999. Quantification of Bacillus thuringiensis insect control protein CrylAc over time in Bollgard cotton fruit an terminals. J. Econ. Entomol. 92, 13771383.

Hanley AV, Huang ZY, Pett WL, 2003. Effects of dietary transgenic Bt corn pollen on larvae of Apis mellifera and Galleria mellonela. J. Apicult. Res. 42, 77-81.

Klostermeyer EC, Mech SJ, Rasmussen WB, 1973. Sex and weight of Megachile rotundata (Hymenoptera: Megachilidae) progeny associated with provision weights. J. Kansas Entomol. Soc. 46, 536-548.

Lehrman A, 2007. Does pea lectin expressed transgenically in oilseed rape (Brassica napus) influence honeybee (Apis mellifera) larvae? Environ. Biosafe. Res. 6, $1-8$.

Liu B, Xu C, Yan F, Gonc R, 2005. The impacts of the pollen of insect-resistant transgenic cotton on honeybees. Biodivers. Conserv. 14, 3487-3496.

Liu B, Chu C, Xue K, Zhou K, Li X, Liu D, Zheng Y, Xu $\mathrm{C}, 2009$. The oral toxicity of the transgenic Bt+CpTi cotton pollen to honeybess (Apis mellifera). Ecotox. Environ. Safe 72, 1163-1169.

Malone LA, Pham-Delègue M-H, 2001. Effects of transgene products on honey bees (Apis mellifera) and bumblebees. Apidologie 32, 287-304.

Malone LA, Tregidga EL, Todd JH, Burgess EPJ, Philip BA, Markwick NP, Poulton J, Christeller JT, Lester MT, Gatehouse HS, 2002. Effects of ingestion of a biotinbinding protein on adult and larval honey bees. Apidologie 33, 447-458.

Malone LA, Todd JH, Burgess EPJ, Christeller JT, 2004. Development of hypopharyngeal glands in adult honey bees fed with a Bt toxin, a biotin-binding protein and a protease inhibitor. Apidologie 35, 655-664.

McKee BA, Goodman RD, Hornitzky MA, 2004. The transmition of European foulbrood (Melissococcus plutonius) to artificially reared honey bee larvae (Apis mellifera). J. Apicult. Res. 43, 93-100.

Morandin LA, Winston M, 2003. Effects of novel pesticides on bumble bee (Hymenoptera: Apidae) colony 
health and foraging ability. Environ. Entomol. 32, 555-563.

O'Callaghan M, Glare TR, Burgess EPJ, Malone LA, 2005. Effects of plants genetically modified for insect resistance on nontarget organims. Annu. Rev. Entomol. 50, 292.

Pyke GH, 1978. Optimal body size in bumblebees. Oecologia 34, 255-266.

Ramirez-Romero R, Desneux N, Decourtye A, Chaffiol A, Pham-Delègue $\mathrm{MH}, 2008$. Does Cryl Ab protein affect learning performances of the honey bee Apis mellifera L. (Hymenoptera, Apidae)? Ecotoxicol. Environ. Saf. 70, 327-333.

Rose R, Dively GP, Pettis J, 2007. Effects of Bt corn pollen on honey bees: emphasis on protocol development. Apidologie 38, 1-11.

SAS Institute, 2001. User's guide: statistics, version 8.2, 6th edn. SAS Institute, Cary, NC.

Silva IC, Message D, Cruz CD, Campos LAO, Sousa-Majer MJ, 2009. Rearing africanized honey bee (Apis mellifera) brood under laboratory conditions. Genet. Mol. Res. 8, 623-629.

van der Steen JJM, 2001. Review of the methods to determine the hazard and toxicity of pesticides to bumblebees. Apidologie 32, 399-406.

Vandenberg JD, Shimanuki H, 1987. Tecnique for rearing worker honeybees in the laboratory. J. Apicult. Res. 26, 90-97.

Wilkinson MJ, 2004. Abandoning 'responsive' GM risk assessment. Trends Biotechnol. 22, 438-439.

Wilkinson MJ, Sweet J, Poppy GM, 2003. Abandoning 'responsive' GM risk assessment. Trends Plant Sci. 8, 208-221.

Wright DJ, Iqbal M, Granero F, Ferre J, 1997. A change in a single midgut receptor in the diamondback moth (Plutella xylostella) is only in part responsible for field resistance to Bacillus thuringiensis subsp. kurstaki and $B$. thuringiensis subsp. aizawai. Appl. Environ. Microb. 63, 1814-1819. 